\title{
Preprint
}

\section{A narrative review of newlv approved drugs for COVID-19}

Dr. Rajmohan Seetharaman*, Dr. Jaisen Lokhande**

*2nd yr Resident (iD 0000-0002-4605-2805

**Assistant Professor iD 0000-0001-5614-1804

Department of Pharmacology, LTMMC \& GH, Sion, Mumbai

Abstract:

COVID-19 disease is swiftly spreading over the globe. There were no specific approved drugs or therapies at the start of the pandemic. Hence, the management of these patients involves optimized supportive care. Researchers worldwide are analyzing the viral structure viruses pathophysiology to develop new drugs and repurpose the currently approved drugs. Regulatory authorities worldwide, such as the USFDA, EMA, CDSCO, etc. are working closely with these scientists. They are expediting their efforts by providing advice, technical assistance, regulatory flexibility, and leveraging on scientific information from the trials conducted across various parts of the globe. These efforts have led to emergency use authorizations and restricted emergency use approvals of a few drugs, namely remdesivir, favipiravir, and 2\% propofol emulsion for use in COVID-19 patients. The USFDA has revoked the approval of chloroquine and hydroxychloroquine. Many more new drugs are in the pipeline for their antiviral or immunomodulatory or other supportive mechanisms of action. These drugs are under the radar of regulatory authorities who are monitoring their efficacy and safety firmly as the world hopes to find a solution to combat this pandemic.

Keywords: SARS-CoV-2, pandemic, regulatory authorities, accelerated approval, pharmacotherapy.

The coronavirus disease 2019 (COVID-19) pandemic which was caused by severe acute respiratory syndrome coronavirus 2 (SARS-CoV-2) which first emerged in Wuhan, China in December 2019 has advanced into a worldwide pandemic with $16,558,289$ cases and 656,093 deaths being accounted for overall till July $29^{\text {th }}$ 2020.1-3 The symptoms of SARS-CoV-2 vary from an asymptomatic disease or mild fever, cough or pneumonia to extremely life-threatening complications acute respiratory distress syndrome and multi-system organ failure which may ultimately result to death ${ }^{4-5}$. Wu $\mathrm{C}$ et al. and few other authors reported that elderly patients, immunocompromised patients and those with preexisting cardiovascular or respiratory conditions seem, by all accounts, to be at the highest risk for lifethreatening complications. ${ }^{6-7}$ 
Multiple therapeutic options involving investigational new drugs and the repurposing of existing drugs have been explored for the management of COVID-19. The pharmacotherapy ranges from pre and post-exposure prophylaxis to targeting the replication cycle and immune medicated processes resulting in life-threatening complications. ${ }^{8}$ Without a demonstrated effective therapy, current management includes supportive care with antibiotics, invasive and non-invasive oxygen support, and off-label use of drugs, which are now under investigation. ${ }^{9}$

Drug development is an expensive and timely process with a high attrition rate, which is unsatisfactory in setting to the current global emergency. ${ }^{10}$ Therefore the United States Food and Drug Administration (USFDA) has propelled an emergency program for possible therapies known as the Coronavirus Treatment Acceleration Program (CTAP), which uses every possible method to evaluate investigational drugs and expedite the approval process for drugs showing promising efficacy and adequate safety. ${ }^{11}$ The Drug Controller General of India (DCGI) has likewise offered several waivers for accelerating the procedure from fast track approval of a repurposed drug to waiving animal studies and offering various flexible pathways which would have otherwise taken several months. ${ }^{12}$

Stages of the replication cycle of SARS-CoV-2 as drug targets

SARS-CoV-2 is known to have four structural proteins, namely spike (S), envelope $(\mathrm{E})$, membrane $(\mathrm{M})$, and nucleocapsid $(\mathrm{N})$, which encapsulates the single-stranded viral RNA. Spike is the protein that interacts with the host cell receptors, and it is cleaved into S1 and S2 by the host cell protease, such as transmembrane protease serine-2 (TMPRSS2). The function of S1 is to bind to the host cell surface receptor, whereas the role of $\mathrm{S} 2$ is to mediate membrane fusion.

Recent protein modeling studies of spike protein suggest that SARS-CoV-2 has a strong binding affinity to human angiotensin-converting enzyme-2 (ACE-2) receptors and likely uses them as a mechanism for cell entry. ACE-2 receptors are highly expressed in type II alveolar pneumocytes of the lungs. However, they are also present in various other extrapulmonary sites such as the heart, kidney, endothelium, and intestine. Previous studies in mice demonstrated that binding of SARS-CoV-2 spike protein to ACE-2 receptor down-regulates the receptor and thereby contributes to severe lung injury.

After uncoating, the genomic RNA of the SARS-CoV-2 acts on m-RNA using host cell ribosome for translation of the replicase poly-protein 1a and 1ab (ppla and pplab). Autoproteolytic cleavage of these poly-proteins by the protease enzyme then produces several non-structural proteins, including RNA dependent RNA polymerase $(\mathrm{RdRp})$, helicase, and non-structural proteins $3,4 \& 6$. These non-structural proteins $3,4 \& 6$ are responsible for anchoring the SARS-CoV-2 replication/transcription complex through recruitment of intracellular endoplasmic reticulum membranes to 
form double-membrane vesicles (DMV). RdRp and helicase localize to DMV's and drive the production of subgenomic RNA's (Sg RNA`s) from which structural and accessory proteins are produced in the next phase of translation.

Once synthesized, the transmembrane structural proteins $\mathrm{S}, \mathrm{M} \& \mathrm{E}$ are inserted and folded in the endoplasmic reticulum (ER) and then transported to the ER-Golgi intermediate compartment (ERGIC). On the other hand, the $\mathrm{N}$ proteins bind to the viral genome RNA in the cytoplasm to form nucleocapsid. Once the final virion assembly occurs in the intermediate compartment, mature virions are released via smooth-walled vesicles by exocytosis. ${ }^{13-14}$ Various drugs acting at different stages of this replication cycle have been explored and repurposed for the treatment of COVID-19 out of which various regulatory authorities have approved a few, which are as follows:

\section{Remdesivir:}

It is a broad-spectrum antiviral (nucleotide analog prodrug) targeting the RNA dependent RNA polymerase. ${ }^{15}$ FDA issued emergency use authorization (EUA) on May $1^{\text {st }} 2020$ for use in hospitalized adults or children with severe disease (defined as oxygen saturation [SpO2] 94\% or lower on room air or requiring supplemental oxygen, extracorporeal membrane oxygenation or mechanical ventilation) and required the drug to be administered by a healthcare provider via $\mathrm{I} / \mathrm{V}$ infusion in doses recommended by EUA. The EUA requires the healthcare facilities and healthcare providers administering remdesivir to agree to precise obligatory recordkeeping and reporting requirements (including adverse event reporting to FDA MedWatch. ${ }^{16-17}$ Remdesivir is currently being evaluated by European Medicines Agency's (EMA`s) Committee for Medicinal Products for Human Use (CHMP), for conditional marketing authorization for the treatment of COVID-19.18 Pharmaceuticals and Medical Devices Agency; Japan approved it on May 7th 2020 based on article 14-3 of PMD act. 19 Considering the global emergency and unmet medical need for COVID-19 disease, Central Drugs Standard Control Organization (CDSCO) on June $21^{\text {st }} 2020$ has approved restricted emergency use of remdesivir injectable formulations for the treatment of patients with severe COVID-19 infection subject to various conditions and restrictions. ${ }^{20}$

\section{Dosage:}

Recommended EUA dosage for adults and children weighing $40 \mathrm{~kg}$ or more: A loading dose of $200 \mathrm{mg}$ by IV infusion on day 1, followed by maintenance doses of $100 \mathrm{mg}$ by IV infusion once daily from day 2. Optimal duration of treatment not known. The recommended total treatment duration is ten days for patients requiring invasive mechanical ventilation and/or extracorporeal membrane oxygenation (ECMO). For those not requiring invasive mechanical ventilation and/or ECMO, the recommended total treatment duration is five days. Extension of treatment may occur 
if the patient does not demonstrate clinical improvement for up to five additional days (i.e., up to a total treatment duration of ten days).

Recommended EUA dosage for children weighing 3.5 to less than $40 \mathrm{~kg}$ (using the lyophilized powder formulation only): A loading dose of $5 \mathrm{mg} / \mathrm{kg}$ by IV infusion on day 1 , which is followed by maintenance doses of $2.5 \mathrm{mg} / \mathrm{kg}$ by IV infusion once daily from day 2. Optimal duration of treatment not known. The recommended total treatment duration is ten days for patients requiring invasive mechanical ventilation and/or ECMO. For those not requiring invasive mechanical ventilation and/or ECMO, the recommended total treatment duration is five days. Extension of treatment may occur if the patient does not demonstrate clinical improvement for up to 5 additional days (i.e., up to a total treatment duration of 10 days).21(Table I)

\section{Chloroquine Phosphate and Hydroxychloroquine:}

These are antimalarial drugs which showed antiviral activities in various in vitro studies. Chloroquine increases the vacuolar and endosomal $\mathrm{pH}$ resulting in decreased functioning by inhibiting endocytosis and inhibiting vacuolar ATPase (vATPase) proton pump on the lysosomal surface. It acts as a zinc ionophore, which increases $\mathrm{Zn} 2+$ entry into the cell, which has shown to inhibit viral replication in in-vitro studies. It also competitively inhibits the binding of the spike protein to the sialic acid on the cell membrane's surface. The immunomodulatory effects theoretically promise anti-inflammatory benefits in the severe stages of COVID-19. Hydroxychloroquine has a similar mechanism of action as chloroquine phosphate. Hydroxyl analog of chloroquine with similar mechanisms of action and adverse effects; may have more favorable dose-related toxicity profile than chloroquine, but cardio-toxicity (e.g., prolonged QT interval) is a concern with both drugs. ${ }^{22-25}$

The DCGI has also approved the protocol which was recommended by the ICMR national task force for restricted use in high-risk contacts. ${ }^{26}$ FDA had issued a EUA on March 28th, 2020 that permitted distribution of the drug from the strategic national stockpile (SNS) for use only in adults and adolescents weighing $50 \mathrm{~kg}$ or more hospitalized with COVID-19 for whom a clinical trial is not available or participation not feasible. FDA also issued a safety alert regarding adverse cardiac effects and cautioned against the medical use of chloroquine or hydroxychloroquine outside of a clinical trial or hospital setting. ${ }^{27-29}$ Effective June 15th, 2020, FDA has revoked the EUA for chloroquine and hydroxychloroquine. The EUA was issued based on a review of new information and reevaluation of the available data. The FDA concluded that the original criteria for issuance of the EUA for these drugs are no longer met. FDA concluded that it is unlikely that chloroquine and hydroxychloroquine may be effective in treating COVID-19 on the basis of the totality of scientific evidence available, and considering the incoming reports of associated serious cardiac adverse events and several newly reported cases of methemoglobinemia in COVID-19 patients, the already known and potential benefits 
of chloroquine and hydroxychloroquine do not outweigh the known and potential risks associated with the use authorized by the EUA. ${ }^{30}$

Dosage: For the treatment of hospitalized adults and adolescents weighing $50 \mathrm{~kg}$ or more, the recommended dosage of chloroquine phosphate was $1 \mathrm{~g}$ on day 1 , then 500 mg daily for 4- 7 days of total treatment based on clinical evaluation and the proposed dosage of hydroxychloroquine was $800 \mathrm{mg}$ on day 1, then $400 \mathrm{mg}$ daily for 4-7 days of total treatment based on clinical evaluation. ${ }^{31-32}$ (Table I)

The basis for the FDA decision to revoke the EUA for hydroxychloroquine and chloroquine is summarized below:

1) Suggested hydroxychloroquine and chloroquine dosage regimens, as detailed in the EUA fact sheets for healthcare providers, are unlikely to produce an antiviral effect.

2) There have been no consistent replications of earlier observations of decreased viral shedding with hydroxychloroquine or chloroquine treatment. Recent data from a randomized controlled trial assessing the probability of negative conversion showed no difference between hydroxychloroquine and standard of care alone.

3) Current United States treatment guidelines do not recommend using chloroquine or hydroxychloroquine in patients hospitalized with COVID-19 outside of a clinical trial, and the guidelines issued by NIH now also recommend against its use outside a clinical trial.

4) Recent evidence obtained from a large, randomized, controlled trial showed no evidence of benefit in outcomes assessed, such as mortality or hospital length of stay or need for mechanical ventilation for hydroxychloroquine treatment in hospitalized patients with COVID-19.30

Favipiravir:

It is a broad-spectrum antiviral. The active favipiravir-RTP selectively inhibits RNA polymerase and prevents replication of the viral genome. ${ }^{33}$ Considering the global emergency and unmet medical need for COVID-19 disease, CDSCO June $21^{\text {st }} 2020$ has approved restricted emergency use of oral favipiravir tablets for mild to moderate COVID-19 infection subject to various conditions and restrictions under the brand name of "fabiflu". ${ }^{20}$

Dosage: Favipiravir was used at a dosage of $1600 \mathrm{mg}$ twice daily on day 1, which was followed by $600 \mathrm{mg}$ twice daily thereafter for 7-10 or 14 days in several openlabel COVID-19 studies in China. ${ }^{34,35}$ (Table I)

Other antivirals under evaluation: 
Other antiviral drugs currently under investigation are baloxavir, HIV protease inhibitors (namely; lopinavir, atazanavir, darunavir, nelfinavir, saquinavir, and tipranavir), neuraminidase inhibitors (namely; oseltamivir and zanamivir) and umifenovir. ${ }^{36-37}$

\section{SARS-CoV-2-Mediated Inflammatory Responses as drug targets}

Studies carried out earlier suggest that the immune response in COVID-19 patients is two-phased. In moderate disease, immune cells produce inflammatory cytokines to reduce the viral load. During this stage, it might be beneficial to use therapies to stimulate the immune response. During severe stages, COVID-19 patients exhibit a high cytokine level or hyper inflammation, which may lead to severe pulmonary damage resulting in acute respiratory distress syndrome (ARDS). Reversing pulmonary damage is a significant hurdle in treating COVID-19, and ARDS is one of the leading causes of mortality in these patients.

The origin of cytokines involved in the SARS-CoV-2 related cytokine storm is yet to be determined as researchers have not entirely assessed the complete immune response. One theory related to the cytokine storm involves rapid viral replication, which leads to large scale cell pyro-apoptosis. The macrophages are then recruited into the lungs and will, in turn, amplify the inflammatory response. Studies comparing serum cytokines levels in infected individuals comprising of patients exhibiting marked symptoms and those with severe symptoms have shown increased levels of IL-6, IL-10, TNF-alpha, and soluble IL-2R receptor associated with disease severity. Another study examined patients with pneumonia comparing cytokines and chemokine's in patients admitted in the intensive care unit (ICU) as compared to those who were not admitted in ICU's. They found the IL-2, IL-7, G-CSF, IP-10, MCP-1, and MIP-1 are all elevated in the patients admitted in ICU's. ${ }^{38-39}$

While the patient's own immune system may cause respiratory distress syndrome and multi-organ failure leading to the death of some patients, treatment strategies may not be as simple as using a broad anti-inflammatory drug. Broad anti-inflammatory drugs may impair the patient's ability to eliminate the viral pathogen and may make the patient more susceptible to secondary infection, which could worsen the outcome. Understanding the specific cytokines involved in the COVID-19 cytokine storm is essential for developing treatments. Hence based on the observations made by earlier studies multiple therapeutic options are being explored and repurposed to manage the cytokine storm induced by SARS-CoV-2 at the severe stage of COVID-19.38-39 Currently immunomodulators are still under evaluation by various regulatory authorities with only one drug which is supportive for mechanical ventilation being approved by the USFDA which is as follows;

Itolizumab: 
It is a humanized recombinant anti-CD6 monoclonal antibody of IgG1 iso-type that binds to domain 1 of CD6, thereby immunomodulating human lymphocytes without interfering with the binding of CD6 to the activated leukocyte-cell adhesion molecule. CDSCO on July 11th 2020 has approved Restricted Emergency Use of Itolizumab injection $25 \mathrm{mg} / 5 \mathrm{~mL}$ solution for the treatment of cytokine release syndrome (CRS) in moderate to severe ARDS (acute respiratory distress syndrome) patients due to COVID-19.40(Table I)

Propofol 2\%, emulsion:

It is a sedative-hypnotic. On May 8th, 2020 USFDA approved Propofol 2\%, emulsion to maintain sedation via continuous infusion in patients greater than 16 years old with suspected or confirmed COVID-19 who require mechanical ventilation in an intensive care unit (ICU) setting. ${ }^{41}$ (Table I)

Table I: A summary of newly approved drugs for COVID-19

\begin{tabular}{|c|c|c|c|}
\hline $\begin{array}{c}\text { Drug \& mechanism of } \\
\text { action }\end{array}$ & $\begin{array}{c}\text { Approval date \& } \\
\text { approving regulatory } \\
\text { body }\end{array}$ & $\begin{array}{c}\text { Dosage \& } \\
\text { recommended duration } \\
\text { of therapy }\end{array}$ & Indication \\
\hline $\begin{array}{l}\text { 1) Remdesivir } \\
\text { (Broad-spectrum } \\
\text { antiviral targeting the } \\
\text { RNA dependent RNA } \\
\text { polymerase) }\end{array}$ & $\begin{array}{l}\text { 1) May 1st 2020: } \\
\text { USFDA } \\
\text { 2) May 7th 2020: } \\
\text { PMDA, Japan } \\
\text { 3) June 21st 2020: } \\
\text { CDSCO, India }\end{array}$ & $\begin{array}{l}\text { 1) Adults and children } \\
\text { weighing } 40 \mathrm{~kg} \text { or } \\
\text { more: } 200 \mathrm{mg} \mathrm{I} / \mathrm{V} \text { day } \\
1,100 \mathrm{mg} \mathrm{I} / \mathrm{N} \text { day } 2 \\
\text { onwards. } \\
\text { Recommended } \\
\text { duration: } 5-10 \text { days. } \\
\text { 2) Children weighing } \\
3.5 \text { to }<40 \mathrm{~kg}: 5 \mathrm{mg} / \\
\mathrm{kg} \mathrm{I} / \mathrm{N} \text { day } 1,2.5 \mathrm{mg} / \\
\mathrm{kg} \mathrm{I} / \mathrm{N} \text { day } 2 \\
\text { onwards. } \\
\text { Recommended } \\
\text { duration: } 5-10 \text { days. }\end{array}$ & $\begin{array}{l}\text { Hospitalized adults or } \\
\text { children with severe } \\
\text { COVID-19 infection }\end{array}$ \\
\hline $\begin{array}{l}\text { 2) Chloroquine } \\
\text { Phosphate and } \\
\text { Hydroxychloroquine } \\
\text { (antiviral and anti- } \\
\text { inflammatory effects) }\end{array}$ & $\begin{array}{l}\text { 1) Approval: March } \\
\text { 28th, 2020, USFDA } \\
\text { 2) Revoked approval: } \\
\text { June 15th, } 2020\end{array}$ & $\begin{array}{l}\text { 1) Chloroquine } \\
\text { Phosphate: } 1 \mathrm{~g} \text { oral } \\
\text { on day } 1,500 \mathrm{mg} \\
\text { oral daily day } 2 \\
\text { onwards. } \\
\text { Recommended duration: } \\
4-7 \text { days. } \\
\text { 2) Hydroxychloroquine: } \\
800 \mathrm{mg} \text { oral on day } \\
1,400 \text { mg oral daily } \\
\text { day } 2 \text { onwards. } \\
\text { Recommended duration: } \\
4-7 \text { days. }\end{array}$ & $\begin{array}{l}\text { Adults and adolescents } \\
\text { weighing } 50 \mathrm{~kg} \text { or more } \\
\text { hospitalized with } \\
\text { COVID-19 (for whom a } \\
\text { clinical trial is not } \\
\text { available or participation } \\
\text { not feasible). }\end{array}$ \\
\hline
\end{tabular}




\begin{tabular}{|c|c|c|c|}
\hline $\begin{array}{c}\text { Drug \& mechanism of } \\
\text { action }\end{array}$ & $\begin{array}{l}\text { Approval date \& } \\
\text { approving regulatory } \\
\text { body }\end{array}$ & $\begin{array}{c}\text { Dosage \& } \\
\text { recommended duration } \\
\text { of therapy }\end{array}$ & Indication \\
\hline $\begin{array}{l}\text { 3) Favipiravir } \\
\text { (Broad-spectrum } \\
\text { antiviral selectively } \\
\text { inhibits RNA } \\
\text { polymerase) }\end{array}$ & $\begin{array}{l}\text { June 21st 2020: } \\
\text { CDSCO, India }\end{array}$ & $\begin{array}{l}1600 \mathrm{mg} \text { oral twice daily } \\
\text { on day } 1,600 \mathrm{mg} \text { oral } \\
\text { twice daily day } 2 \\
\text { onwards. } \\
\text { Recommended duration: } \\
7-10 \text { days. }\end{array}$ & $\begin{array}{l}\text { Mild to moderate } \\
\text { COVID-19 infection }\end{array}$ \\
\hline $\begin{array}{l}\text { 4) Itolizumab } \\
\text { (Humanized recombinant } \\
\text { anti-CD6 monoclonal } \\
\text { antibody) }\end{array}$ & $\begin{array}{l}\text { July 11th 2020: CDSCO, } \\
\text { India }\end{array}$ & $25 \mathrm{mg} / 5 \mathrm{~mL} \mathrm{I} / \mathrm{V}$ & $\begin{array}{l}\text { Cytokine release } \\
\text { syndrome (CRS) in } \\
\text { moderate to severe } \\
\text { ARDS due to COVID-19 }\end{array}$ \\
\hline $\begin{array}{l}\text { 5) Propofol 2\%, } \\
\text { emulsion } \\
\text { (sedative-hypnotic) }\end{array}$ & May 8th, 2020, USFDA & $2 \%$, emulsion, I/N & $\begin{array}{l}\text { To maintain sedation via } \\
\text { continuous infusion in } \\
\text { patients greater than } 16 \\
\text { years old with suspected } \\
\text { or confirmed COVID-19 } \\
\text { who require mechanical } \\
\text { ventilation in the ICU }\end{array}$ \\
\hline
\end{tabular}

Other immunomodulators under evaluation

Immunomodulators currently under investigation include anakinra, baricitinib, colchicine, systemic corticosteroids (dexamethasone, hydrocortisone, methylprednisolone, and prednisolone), inhaled corticosteroids (ciclesonide), interferons (namely; IFN beta-1a. IFN beta-1b, IFN alfa, and Peginterferon lambda-1a), ruxolitinib, sarilumab, siltuximab, sirolimus, and tocilizumab. ${ }^{36-37}$

Other drugs and therapies under evaluation

Other drugs under evaluation include azithromycin, ascorbic acid, epoprostenol (inhaled), nitric oxide (inhaled), Angiotensin Converting Enzyme (ACE) Inhibitors, Angiotensin II Receptor Blockers (ARBs), anticoagulants, COVID-19 convalescent plasma, famotidine, HMG-CoA reductase inhibitors (statins), immune globulin (IGIV, IVIG, gamma-globulin), ivermectin, nebulized drugs, niclosamine, nitazoxanide, nonsteroidal anti-inflammatory agents (namely; ibuprofen and indomethacin), a tissue plasminogen activator ( $\mathrm{t}-\mathrm{PA}$; alteplase) and Chinese herbal medicines. ${ }^{36-37}$

\section{Conclusion:}

The COVID-19 pandemic presents the most significant crisis for public health and the world economy in the last 100 years. Numerous drugs have been used clinically after learning from severe acute respiratory syndrome (SARS) and the Middle East respiratory syndrome (MERS), with ongoing clinical trials evaluating their efficacy 
and safety. Few novel therapies have also been proposed after taking into consideration the unique viral structure and distinct pathogenesis. We hope that a portion of these drugs breeze through the assessment of regulatory authorities in the coming months and strengthen the global healthcare system in their battle against this pandemic.

\section{Conflict of interest: Nil}

Funding: Nil

References:

1) Grein J, Ohmagari N, Shin D, Diaz G, Asperges E, Castagna A, Feldt T, Green G, Green ML, Lescure FX, Nicastri E. Compassionate use of remdesivir for patients with severe Covid-19. New England Journal of Medicine. 2020 Apr 10.

2) Spinelli A, Pellino G. COVID-19 pandemic: perspectives on an unfolding crisis. Br J Surg. 2020 Mar 19;10.

3) WHO COVID-19 Dashboard [Internet]. Covid19.who.int. 2020 [cited 5 May 2020]. Available from: https://covid19.who.int

4) Bi Q, Wu Y, Mei S, Ye C, Zou X, Zhang Z, Liu X, Wei L, Truelove SA, Zhang T, Gao W. Epidemiology and transmission of COVID-19 in 391 cases and 1286 of their close contacts in Shenzhen, China: a retrospective cohort study. The Lancet Infectious Diseases. 2020 Apr 27.

5) Rodriguez-Morales AJ, Cardona-Ospina JA, Gutiérrez-Ocampo E, VillamizarPeña R, Holguin-Rivera Y, Escalera-Antezana JP, Alvarado-Arnez LE, BonillaAldana DK, Franco-Paredes C, Henao-Martinez AF, Paniz-Mondolfi A. Clinical, laboratory and imaging features of COVID-19: A systematic review and metaanalysis. Travel medicine and infectious disease. 2020 Mar 13:101623.

6) Wu C, Chen X, Cai Y, Zhou X, Xu S, Huang H, Zhang L, Zhou X, Du C, Zhang Y, Song J. Risk factors associated with acute respiratory distress syndrome and death in patients with coronavirus disease 2019 pneumonia in Wuhan, China. JAMA internal medicine. 2020 Mar 13.

7) Weiss P, Murdoch DR. Clinical course and mortality risk of severe COVID-19. The Lancet. 2020 Mar 28;395(10229):1014-5.

8) Wu R, Wang L, Kuo HC, Shannar A, Peter R, Chou PJ, Li S, Hudlikar R, Liu X, Liu Z, Poiani GJ. An update on current therapeutic drugs treating COVID-19. Current Pharmacology Reports. 2020 May 11:1.

9) Peng F, Tu L, Yang Y, Hu P, Wang R, Hu Q, Cao F, Jiang T, Sun J, Xu G, Chang C. Management and treatment of COVID-19: the Chinese experience. Canadian Journal of Cardiology. 2020 Apr 17.

10) Lythgoe MP, Middleton P. Ongoing clinical trials for the management of the COVID-19 pandemic. Trends in Pharmacological Sciences. 2020 Apr 9.

11) Coronavirus Treatment Acceleration Program (CTAP) [Internet]. U.S. Food and Drug Administration. 2020 [cited 22 June 2020]. Available from: https:// 
www.fda.gov/drugs/coronavirus-covid-19-drugs/coronavirus-treatmentacceleration-program-ctap

12) CDSCO: Rapid response regulatory framework for COVID-19 [Internet]. Cdsco.gov.in. 2020 [cited 22 June 2020]. Available from: https://cdsco.gov.in/ opencms/opencms/system/modules/CDSCO.WEB/elements/ download file division.jsp?num id $=\mathrm{NTc} 4 \mathrm{Mw}==$

13) Astuti I. Severe Acute Respiratory Syndrome Coronavirus 2 (SARS-CoV-2): An overview of viral structure and host response. Diabetes \& Metabolic Syndrome: Clinical Research \& Reviews. 2020 Apr 18.

14) Schoeman D, Fielding BC. Coronavirus envelope protein: current knowledge. Virology journal. 2019 Dec;16(1):1-22.

15) Gordon CJ, Tchesnokov EP, Woolner E, Perry JK, Feng JY, Porter DP, GÃ $\llbracket$ tte M. Remdesivir is a direct-acting antiviral that inhibits RNA-dependent RNA polymerase from severe acute respiratory syndrome coronavirus 2 with high potency. Journal of Biological Chemistry. 2020 May 15;295(20):6785-97.

16) US Food and Drug Administration. Letter of authorization: Emergency use authorization for use of remdesivir for the treatment of hospitalized 2019 coronavirus disease (COVID-19) patients. 2020 May 1. From FDA website. (https://www.fda.gov/media/137564/download)

17) US Food and Drug Administration. Fact sheet for health care providers: Emergency use authorization (EUA) of remdesivir (GS-5734). Revised 2020 Jun. From FDA website. (https:// www.fda.gov/media/137566/download)

18) EMA receives application for conditional authorisation of first COVID-19 treatment in the EU - European Medicines Agency [Internet]. European Medicines Agency. 2020 [cited 22 June 2020]. Available from: https:// www.ema.europa.eu/en/news/ema-receives-application-conditional-authorisationfirst-covid-19-treatment-eu

19) PMDA's Efforts to Combat COVID-19 | Pharmaceuticals and Medical Devices Agency [Internet]. Pmda.go.jp. 2020 [cited 22 June 2020]. Available from: https://www.pmda.go.jp/english/about-pmda/0002.html

20) Approval of Favipiravir Tablets to Glenmark Pharmaceuticals and Remdesivir Injection to Cipla Ltd and Hetero Drugs [Internet]. Cdsco.gov.in. 2020 [cited 22 June 2020]. Available from: https://www.cdsco.gov.in/opencms/opencms/system/ modules/CDSCO.WEB/elements/download file division.jsp? num $\mathrm{id}=\mathrm{NjAwOA}==$

21) US Food and Drug Administration. Fact sheet for health care providers: Emergency use authorization (EUA) of remdesivir (GS-5734). Revised 2020 Jun. From FDA website. (https:// www.fda.gov/media/137566/download)

22) Devaux CA, Rolain JM, Colson P et al. New insights on the antiviral effects of chloroquine against coronavirus: what to expect for COVID-19?. Int J Antimicrob Agents. 2020; :105938. (PubMed 32171740) (DOI 10.1016/j. ijantimicag.2020.105938)

23) Colson P, Rolain JM, Lagier JC et al. Chloroquine and hydroxychloroquine as available weapons to fight COVID-19. Int J Antimicrob Agents. 2020; :105932. Editorial. (PubMed 32145363) (DOI 10.1016/j. ijantimicag.2020.105932) 
24) Rolain MJ, Colson, Raoult D. Recycling of chloroquine and its hydroxyl analogue to face bacterial, fungal and viral infections in the 21 st century. Int $\mathrm{J}$ Antimicrob Agents. 2007; 30:297-308. (PubMed 17629679) (DOI 10.1016/ j.ijantimicag.2007.05.015)

25) Chloroquine and hydroxychloroquine: Current evidence for their effectiveness in treating COVID-19 [Internet]. CEBM. 2020 [cited 22 June 2020]. Available from: https://www.cebm.net/covid-19/chloroquine-and-hydroxychloroquinecurrent-evidence-for-their-effectiveness-in-treating-covid-19/

26) Advisory on the use of Hydroxychloroquine [Internet]. Mohfw.gov.in. 2020 [cited 22 June 2020]. Available from: https://www.mohfw.gov.in/pdf/ AdvisoryontheuseofHydroxychloroquinasprophylaxisforSARSCoV2infection.pdf

27) US Food and Drug Administration. Letter of authorization: Emergency use authorization for use of chloroquine phosphate or hydroxychloroquine sulfate supplied from the strategic national stockpile for treatment of 2019 Coronavirus disease. 2020 Mar 28. From FDA website. (https://www.fda.gov/media/136534/ download)

28) US Food and Drug Administration. Fact sheet for health care providers emergency use authorization (EUA) of chloroquine phosphate supplied from the strategic national stockpile for treatment of COVID-19 in certain hospitalized patients. Dated 2020 Mar 27. From FDA website. (https://www.fda.gov/media/ 136535/download)

29) US Food and Drug Administration. FDA drug safety communication: FDA cautions against use of hydroxychloroquine or chloroquine for COVID-19 outside of the hospital setting or a clinical trial due to risk of heart rhythm problems. April 24, 2020. Available at https://www.fda.gov/media/137250/ download.

30) US Food and Drug Administration. Letter regarding revocation of emergency use authorization (EUA) for emergency use of chloroquine phosphate and hydroxychloroquine sulfate supplied from the strategic national stockpile for treatment of Coronavirus disease 2019. 2020 Jun 15. Available at https:// www.fda.gov/media/138945/download

31) U.S. National Library of Medicine. ClinicalTrials.gov. Accessed 2020 Jun 15. Available at https://www.clinicaltrials.gov/.

32) Chen J, Liu D, Liu L et al. [A pilot study of hydroxychloroquine in treatment of patients with moderate COVID-19]. J Zhejiang Univ. 2020; 49:215-19. (PubMed 32391667) (DOI 10.3785/j.issn.1008-9292.2020.03.03).

33) De Clercq E. New nucleoside analogues for the treatment of hemorrhagic fever virus infections. Chem Asian J. 2019;14:3962-3968. PMID: 31389664 DOI: 10.1002/asia.201900841

34) McGrane V. Massachusetts to launch first US trial of Japanese coronavirus drug. Boston Globe. Updated 2020 Apr 15. Accessed 2020 Apr 14. Available at: https:// www.bostonglobe.com/2020/04/07/metro/massachusetts-launch-first-trialjapanese-covid-drug 
35) Cai Q, Yang M, Liu D et al. Experimental treatment with favipiravir for COVID-19: an open-label control study. Engineering (Beijing). 2020. PMID: 32346491 DOI: $10.1016 /$ j.eng.2020.03.007

36) Wu R, Wang L, Kuo HC, Shannar A, Peter R, Chou PJ, Li S, Hudlikar R, Liu X, Liu Z, Poiani GJ. An update on current therapeutic drugs treating COVID-19. Current Pharmacology Reports. 2020 May 11:1.

37) Assessment of Evidence for COVID-19-Related Treatments [Internet]. Ashp.org. 2020 [cited 22 June 2020]. Available from: https://www.ashp.org/-/media/assets/ pharmacy-practice/resource-centers/Coronavirus/docs/ASHP-COVID-19Evidence-Table.ashx

38) Sun X, Wang T, Cai D, Hu Z, Liao H, Zhi L, Wei H, Zhang Z, Qiu Y, Wang J, Wang A. Cytokine storm intervention in the early stages of COVID-19 pneumonia. Cytokine \& Growth Factor Reviews. 2020 Apr 25.

39) Catanzaro M, Fagiani F, Racchi M, Corsini E, Govoni S, Lanni C. Immune response in COVID-19: addressing a pharmacological challenge by targeting pathways triggered by SARS-CoV-2. Signal Transduction and Targeted Therapy. 2020 May 29;5(1):1-0.

40) Biocon's Breakthrough Drug Itolizumab Receives DCGI Nod for Emergency Use in Moderate to Severe COVID-19 Patients [Internet]. Biocon.com. 2020 [cited 30 July 2020]. Available from: https://www.biocon.com/docs/ Biocon_PR_Itolizumab_Approved_for_Covid_India.pdf

41) FDA emergency use authorisation: Fresenius Kabi Propoven 2\% [Internet]. Fda.gov. 2020 [cited 22 June 2020]. Available from: https://www.fda.gov/media/ 137888/download 